\title{
Women Candidates and Councillors in Scottish Local Government, 1974-2012
}

\begin{abstract}
While significant attention has been paid to the levels of representation of women in both the Westminster Parliament and the Scottish Parliament, much less considered has been given to the position within local government. This article addresses that deficit for Scotland. It shows that for twenty-five years following the reorganisation of local government in Scotland in 1974 there was a slow but relatively steady increase in the numbers of female candidates and councillors, although more recently this appears to have since plateaued somewhat, together with a similar increase in the number of women councillors taking up more senior roles in Scotland's councils. The article analyses the representation of women in Scottish local government over the period from 1974 to 2012 against the backdrop of significant change in Scotland, including a further restructuring of local government and the introduction of the Single Transferable Vote for council elections, the creation of the Scottish Parliament, the rise of the SNP and the decline of the Conservative Party.
\end{abstract}

Keywords: women, local government, Scotland, representation

Over the past forty years or so there have been strong arguments made for greater descriptive representation in elected political institutions. The groups that most commonly feature in such claims are women and ethnic minorities, although women have arguably been the group which have seen the greatest level of attention and of institutional change. The arguments underpinning these ideas are wide ranging, but frequently draw upon notions including legitimacy (Schwindt-Bayer and Mishler, 2005), justice (Phillips, 2005), democracy and participation (Electoral Commission, 2004), links with substantive representation (Celis and Childs, 2008), and better policy making (Bochel and Evans, 2007). However, beyond electoral representation there is evidence of a relatively small gender gap in political participation and political activism more generally in the United Kingdom (Electoral Commission, 2004; Parry, Moyser and Day, 1992; Pattie, Seyd and Whiteley, 2004), with women being as or more likely than men to engage in cause-oriented activism, although somewhat less likely to be active in 'campaign politics', and less likely to belong to voluntary associations (although more likely to be involved in church groups). Nevertheless, women do report being less interested in politics, less likely to discuss politics, and less satisfied with the current system than men (Hansard Society, 2011 and 2014).

Within the United Kingdom's party system, largely as a response to arguments around the need for greater female involvement and representation, at Westminster the Labour Party introduced all women shortlists for some parliamentary seats for the 1997 general election, before losing a legal challenge to that initiative. Following the passage of new legislation Labour was able to use the same approach again in 2005 and 2010, and in large part as a result of this the proportion of women MPs reached 18\% in 1997 and 22\% in 2010. In addition, a Speaker's Conference was established in 2008 to consider issues of representation in the House of Commons, while Labour's initial proposals for reforms of the House of Lords advocated a largely appointed chamber which would be made more representative of British society as a whole in terms of gender, ethnic minorities and faith, although over time this shifted to a suggestion that representation would be based upon elections, with no explicit suggestion of how social divisions should be taken into account (Bochel and Defty, 2012). However, arguably greater progress was made in early elections to the Scottish Parliament and the National Assembly for Wales, which saw the Labour Party using zipping and twinning mechanisms to 
increase the proportion of female candidates, and the SNP and Plaid Cymru also selecting a significant number of women in winnable seats.

Any analysis of gender representation in local government in the United Kingdom demonstrates that women remain significantly under-represented in councils in each of the constituent nations. However, it is the situation in Scotland that is the focus here. Scotland is arguably of particular interest because the country, and its local government system, has undergone a number of significant structural and other changes since the 1970s. These include two sets of restructuring, the rise and consolidation of the Scottish National Party and the relative decline of the Conservative Party in Scotland, pressures from feminists in Scotland, the creation of the Scottish Parliament, and a change in the electoral system for local government from First Past the Post to the Single Transferable Vote. As discussed below, there are some arguments that elements of these, such as the introduction of a proportional electoral system (Norris, 1985; Matland, 2005), and the strong involvement of the women's movement in the campaign for devolution as part of a drive for greater equality (Brown et al., 1998), had potential implications for the representation of women. Against the changing context of the last four decades, this article provides an analysis of the levels of participation and the electoral success, or otherwise, of women candidates in elections for Scottish local authorities since 1974. It then examines the positions held by women councillors within their authorities.

This research draws significantly on the collection of Scottish local election results begun by John Bochel and David Denver in 1974, and continued more recently by David Denver and Hugh Bochel, which have included identifying all women candidates. Full data are available for each set of elections for the period from 1974 to 2012 (some of the data is also available at the Economic and Social Data Service - SN 5319 - British Local Election Database, 1889-2003). Unfortunately, in 2007 changes to the rules for official nomination forms removed the requirement for full names, meaning that since then, in some instances simply initials, or names such as 'Pat', have been used by some candidates, making identification of gender more difficult, although through various means it has nevertheless been possible to do so for virtually every candidate, so that the data for the period since then still provide a clear picture of the situation. It is, therefore, possible to provide as complete coverage as is likely to be available of the electoral participation and performance of women candidates in Scottish local government over the period. In addition, the article also draws upon evidence gathered from local authorities' web pages, supplemented by information from the Municipal Yearbook, and where necessary by telephone or email contact with councils. This provides a picture, for selected years, of the numbers and proportions of female and male councillors in senior positions, and where relevant, the policy areas for which they have been responsible. For the consideration of women candidates and councillors prior to 1974 the research draws primarily on coverage in The Glasgow Herald and The Scotsman newspapers.

\section{Local government in Scotland: the context}

\section{Changing structures}

The elections of 1974 (which were for the new regional and district tiers of government) took place following a major restructuring of local government in Scotland arising from the Wheatley Commission (1969) and the Local Government (Scotland) Act 1973 which arose as a result of concerns about the number of authorities, the disparities in sizes and the fragmentation of responsibility for service provision (Wilson and Game, 2011). This abolished the old system of four counties of cities, twenty-one large burghs, 176 small burghs, thirty-three counties and 196 districts of county, and created in its place a two-tier system of local government for the whole country, with 
the exception of the three main island groups - the Orkneys, Shetlands (each with electorates of just over 13,000) and Western Isles (with an electorate of around 22,500) - which took the form of single-tier authorities to serve the small and geographically dispersed populations of those areas. On the mainland there were nine regional councils, responsible for services such as education and social work, which varied greatly in geographic size (Central covered around 260,000 hectares while Highland covered around 2,600,000 hectares) and population (in 1974 the electorates ranged from just over 75,000 in Borders to nearly 1.8 million in Strathclyde). The district councils, responsible for local services, including social housing, also varied enormously in population (electorates ranged from under 7,000 in Nairn to nearly two-thirds of a million in Glasgow) and geographically, from concentrated urban areas to large rural areas with small and dispersed populations.

The Thatcher governments sought further changes in local government, including reductions in its autonomy and powers (Brown et al., 1998; Wilson and Game, 2011), and structural change, so that from 1996, following the Local Government etc. (Scotland) Act 1994, a new system was introduced imposed by the Conservative Secretary of State with no process of consultation or review (Brown et al., 1998), driven in part by a desire to introduce unitary councils. The new system consisted of 29 new, single tier authorities, plus the three island councils (Wilson and Game, 2011). From 1974 to 2003 all local elections in Scotland took place on the basis of single-member wards and the First Past the Post electoral system. However, following the 2003 Scottish Parliament elections and an agreement between Labour and the Liberal Democrats to form a coalition administration, this was replaced by the single transferable vote, with wards electing three or four councillors (Denver and Bochel, 2007).

\section{The rise of the SNP and decline of the Conservative Party}

There are several other features of the period covered here which make it notable. One was the increasing divergence in the politics of Scotland from other parts of Great Britain, and England in particular. A significant element of this was associated with the rise of the SNP to become one of the main parties in Scottish politics (Brown et al., 1998; Hassan, 2009), with the increase in support for the party becoming obvious early in this period, particularly at the 1974 general elections, although to some extent they did perhaps initially prove something of a false dawn. The 1970 s also saw the emergence of the SNP as a significant force in Scottish local politics, with the party contesting under one-quarter of district council wards in 1974 but more than 40\% in 1977 (Bochel and Denver 1974, 1977). The same period also saw the relative decline of the Conservative Party in Scotland in terms of electoral support, and particularly in relation to parliamentary seats (Brown et al., 1998; Cairney and McGarvey, 2013). While the Conservative Party did not always contest local elections as strongly as Labour, in some areas, and in particular the four major cities, there were Progressive councillors, who in many instances were either Conservatives or closely aligned with the Conservative Party. By the mid-1970s, however, Conservative candidates were increasingly fighting under their party label. The 1980s also saw the impact of the emergence of the SDP and the subsequent alliance with the Liberals that would ultimately lead to the creation of the Liberal Democrats (Mclver, 1996). Tables 1 and 2 provide general election results over the period, although it is important to note that the parties' performance at the Holyrood and local government level has varied from this. Given these changes, Scotland could perhaps be seen as developing into a four-party system over this period (for example, Cairney and McGarvey, 2013).

\section{TABLES 1 AND 2 ABOUT HERE}


While political representation and equality are only some of the concerns of feminism, they are worthy of consideration here. That is the case not least because for much of the 1980s and 1990s there was considerable pressure from women for economic, social and political change in Scotland (for example, Breitenbach et al., 1998), reflecting that in the rest of the United Kingdom and many other countries, but it also fed into the debate on the constitution, including through a concern for more equal representation in the political sphere. For example, among the issues highlighted in $A$ Woman's Claim of Right in Scotland (Woman's Claim of Right Group, 1991) was women's underrepresentation at Westminster and in local government. That much attention during this period was focused on the idea of devolution was unsurprising, given the potential that it seemed to offer for changes in both policies and political representation. The Women's Movement was represented in debates around the creation of a parliament for Scotland, including through the Scottish Constitutional Convention, established in 1989, with one of the working groups set up being the Women's Issues Group, as a result of pressure from women in the political parties, trades unions and women's groups (Brown et al., 1998). The decade before the creation of the Parliament saw women from different parties and other organisations working together to improve the representation of women in the new body (Levy, 1992, Brown et al., 1998). By the early 1990s the Labour Party appeared to have largely accepted the idea of equal representation for men and women in elections for a Scottish Parliament. However, the other main party within the Convention, the Liberal Democrats, did not. Outside the Convention, the Conservatives and the SNP both appeared to favour greater representation of women, but preferred internal, voluntary means (Brown et al., 1998). Following the creation of the Scottish Parliament, as noted above, Labour's commitment to more equal representation did have a significant impact on the make-up of the new legislature (for example, Brown et al, 2002; Russell et al., 2002). However, as discussed elsewhere in this article, despite the aspirations for a 'new', more open and more participatory democracy (see, for example, Brown, 2000; Mitchell, 2000) associated with the campaign for a Scottish Parliament, the example set by the new Parliament in terms of gender make-up and a generally higher profile of equality issues (Breitenbach, 2005), and responsibility for local government being a devolved issue, these did not appear to be reflected in any significant direct or indirect impact upon representation at the local level.

\section{The Scottish Parliament}

The period saw the creation of the Scottish Parliament in 1999, following the support of almost three-quarters of those who voted in a referendum in September 1997 (Denver et al, 2000). The first elections to the Parliament were noteworthy because they used the Additional Member System, and hence gave a more proportionate outcome than First Past the Post. However, perhaps more importantly for women's representation, they were significant partly because of the efforts, noted above, by Labour in particular (Brown, 1999), to achieve something close to gender equality in the selection of candidates, meaning that nearly $40 \%$ of the newly-elected MSPs were female. This fell to $33 \%$ at the 2007 Scottish Parliament elections, when Labour maintained equal numbers with twentythree female and twenty-three male MSPs, and rose slightly in 2011, when a slight fall in the proportion of Labour MSPs who were women was counterbalanced by small rises for the Conservatives and SNP (see Kenny and Mackay (2011) for a fuller description of the position in 2011 and the approaches to gender and selection taken by the political parties). One further consequence of the creation of the Scottish Parliament, that arguably may indirectly have had some impact on the concern of this article, is that from 1999 to 2007 elections to local authorities in Scotland took place on the same day as elections to the Parliament; this, while contributing to higher turnout, may also have deflected interest from local issues (for example, Gould, 2007), and indeed have had some 
bearing upon patterns of voting and possibly candidature at the local level, although it is hard to identify any impact on the electoral participation or performance of women candidates.

\section{Increasing partisanship in local government elections}

Another feature of this period, which arguably had some impact on the numbers of women contesting elections, was the increasing levels of partisanship in Scottish local politics, and alongside this the decline in the number of seats where a candidate was unopposed. In the mid-1970s around $20 \%$ of district council wards were not contested, with the highest proportions of uncontested wards being in Highland, Borders and Dumfries and Galloway, which were also the areas with the lowest levels of electoral involvement by the main parties. In 1977 Bochel and Denver (1977) identified twenty-six district councils which they described as 'partisan' (where Independents won $20 \%$ or fewer of seats), thirteen described as 'non-partisan' (where Independents won more than $80 \%$ of seats), with the remaining fourteen being categorised as 'intermediate'. By 1992 the number of 'non-partisan' districts had fallen to ten. When elections for the new unitary councils took place in 1995 , only five (plus the three Island councils) fell into the 'non-partisan' category, and for the first elections under STV, in 2007, only four councils (plus the Island councils) were 'non-partisan'. Despite this increase in partisanship, immediately following the 1974 reforms there was actually an increase in the number of uncontested wards (from $20.5 \%$ in 1974 to $22.1 \%$ in 1977 and $26.0 \%$ in 1980), but this was entirely due to a fall in the number of contests in non-partisan areas. By 1992 the proportion of uncontested wards had fallen to $13.1 \%$, and in elections to the new councils in 1995 that had fallen further to $4.7 \%$. The 2007 elections saw no uncontested seats.

\section{Local elections in Scotland's four major cities: women candidates and councillors prior to 1974}

There was no consistent collection of the results of Scottish local elections prior to 1974, and any analysis is therefore largely dependent upon the use of newspaper reports, and in particular those of the most 'national' of the Scottish newspapers, The Glasgow Herald (which had the greatest coverage of the west of Scotland, and the Glasgow area in particular), and The Scotsman (which had the greatest coverage of the east of Scotland, and the Edinburgh area in particular). There are a number of potential problems with such sources, not least that they generally reported only those councils and wards where there were electoral competitions, and prior to 1973 there were large numbers of both wards and entire councils which were uncontested, and they are not always clear and consistent in the identification of either party or gender.

Nevertheless, it is perhaps worth reflecting briefly on the position in Scotland in the 1960s, taking two years as examples. In 1961, in the borough elections, eighty-three councils had no contests whatsoever, and even in councils where there were contests some wards remained uncontested. The partial evidence that emerges from newspaper accounts shows that fifty-one women stood in wards where there were elections and that thirty-two of them were elected. By 1967, also in the borough elections, with the number of uncontested boroughs having fallen somewhat to seventy, there were ninety-four women candidates, of whom forty-seven were elected. A similar but perhaps more detailed picture emerges from the study of Scotland's four major cities (Aberdeen, Dundee, Edinburgh and Glasgow). These were arguably unusual in running ahead of much of the country in terms of the degree of party involvement in elections, and consequently the degree of contestation of wards, but, in part resulting from that, there is also better quality data available for them.

In 1961, in Glasgow, eleven of the 109 candidates (10 per cent) for thirty-eight seats were women (three Progressive, five Labour, two Social Credit and one Communist), with three Labour women 
being elected; in Edinburgh, five of the thirty-six candidates for sixteen seats (14 per cent) were women (one Progressive, three Labour and one Liberal), with three Labour and one Progressive being elected; in Aberdeen, where the whole council was elected, there were only five women among the forty-two candidates for the twenty-four seats (12 per cent) (one Communist, three Labour and one Moderate) of whom two Labour women were elected, and in Dundee only two of the twenty-eight candidates for thirteen seats ( 7 per cent) were women (one Labour, one Moderate), with neither being elected.

In 1967, in Glasgow, ten of the 150 candidates for thirty-seven seats were women (7 per cent) (four Progressive, three Labour, two SNP and one Communist), with three Labour and two Progressives being elected; in Edinburgh, eleven of the sixty-four candidates for twenty-five seats (17 per cent) were women (four Progressive, four Labour, two Liberal and one SNP), with three Labour and three Progressives being elected; in Aberdeen there were only five women among the forty-six candidates (11 per cent) for the twelve seats (two Communist, two Liberal and one SNP) of whom none were elected, and in Dundee only one of the forty-eight candidates for twelve seats was a woman, although she was elected for Labour in the only unopposed ward in the city. These elections also reflected a change in Scottish local politics, with the Conservatives having two candidates elected in Edinburgh for the first time.

In the final set of elections prior to the reorganisation of local government, data from the British Local Election Database for 1972 shows that women's participation as both candidates and councillors remained relatively sparse: in Aberdeen only three of the thirty-four candidates (9 per cent) for the twelve seats were women, of whom none were elected; in Dundee there were four women among the fifty-one candidates for twelve seats (8 per cent), again with none being elected; in Edinburgh nine women stood (five for the Conservatives or Progressives) among the seventythree candidates for twenty-three seats (12 per cent), with two being elected (one Labour, one Liberal); while in Glasgow there were twenty-five women (interestingly, all four Liberal candidates were female) among the 153 candidates ( 16 per cent) for the thirty-seven seats, with six being elected (five Labour and one Conservative). Across the four cities there were therefore forty-one women among the 311 candidates for eighty-four seats ( 13 per cent), but only eight were elected, a success rate of just under $20 \%$, compared with one of just over $25 \%$ for male candidates, although the latter was arguably skewed significantly downwards by the numbers of men standing for minor (generally left-wing) parties in Dundee and Glasgow. If those parties are removed from the equation, the success rate for male candidates is over $35 \%$, while for women it increases only slightly, to just over $20 \%$.

\section{Women candidates}

In terms of the involvement of women as candidates in local elections in Scotland, the pattern over the period since 1974 was, for twenty-five years, one of a slow but steady increase. Whereas women constituted only $14.4 \%$ of candidates in the district elections and $12.1 \%$ of candidates in the regional elections of 1974 , they made up $21.6 \%$ of candidates in the district council elections a decade later and $19.7 \%$ in the regional elections of 1986. The elections for the new unitary councils in 1995 saw almost as great a proportion of women candidates (25.8\%) as for the 1992 district elections, where women were better represented in terms of candidates (26.7\%) than at the 1994 regional elections (22.4\%). The proportion of women candidates rose further to $27.7 \%$ in 2003 . Figure 1 makes clear that this pattern is broadly true for all of the political parties, although for Independents the position has arguably been more static, albeit with significant variations over time. More recently, however, the position appears to have become less positive, with the proportion of women candidates falling back to $22.8 \%$ in the first elections under STV in 2007 and 2012. 
FIGURE 1 ABOUT HERE

Looking briefly at the parties, the emergence of the SNP as a force in local elections from the mid1970s was arguably, in some respects, a positive force for women's representation, as at that time the party tended to select higher proportions of women candidates than some of its rivals. Similarly, the 1982 district elections saw the emergence of the SDP, fighting in an alliance with the Liberals, and this coincided with an increase in the proportion of women candidates from these groupings. In 1999, the year of the first elections to the Scottish Parliament, women constituted $27.1 \%$ of candidates, with only Labour of the major parties failing to increase the proportion of women candidates, which was perhaps somewhat ironic given the strenuous efforts that the party was simultaneously making in its attempts to achieve gender balance among its candidates for the Scottish Parliament. Indeed, of the main parties, Labour has generally had the lowest proportion of women candidates, but, as discussed below, because of Labour's electoral success for most of the period, a significant proportion of Scotland's women councillors nevertheless came from the Labour Party.

\section{Women's electoral performance}

Table 3 shows the slow increase in the proportion of Scotland's councillors that have been women, with a slight decline in the two sets of elections since 1999. Clearly, despite the example set by the Scottish Parliament, local government lags behind.

\section{TABLE 3 ABOUT HERE}

It is not simply that there are fewer women candidates and consequently fewer women councillors. As Figure 2 shows, for the entire period since 1974 there has been a gap between the proportion of male candidates who have been elected and the proportion of female candidates who have been elected, although that has closed gradually and in 2012, for the first time, women candidates were proportionately more likely to be elected than their male counterparts $(50.8 \%$ compared with $48.5 \%)$.

\section{FIGURE 2 ABOUT HERE}

The elections to the new unitary councils in 1995 resulted in $22.9 \%$ of councillors being women, up from $21.5 \%$ in the district elections of 1992 and a major improvement on the $17.4 \%$ from the regional elections of 1994. In 1999 there was a further slight increase in the proportion of women councillors, to $23.5 \%$. While 2003 saw the largest proportion of women candidates $(25.0 \%)$, there was a slight decline in the proportion of women councillors, from 23.5 to $22.6 \%$.

The role of party 
Given the importance of party, and perhaps particularly the major parties, in relation to the selection and election of women, it is worth noting that in the context of local politics in Scotland in some areas some or all of the 'major' parties are 'minor parties', with in 2007, for example, Labour, having little presence in the Borders, the Liberal Democrats having no candidates in East Ayrshire or South Ayrshire, and the Conservatives receiving fewer than $8 \%$ of first preference votes in Glasgow and West Dunbartonshire. Only the SNP received more than $15 \%$ of the vote in every mainland council, but in the Island councils, they, as with the other main parties, had little impact.

Unsurprisingly, there have also been significant differences in the proportions of women candidates elected by party, with, in general, Labour being more successful at getting their candidates, including women, elected (Figure 3 ). In the early years of the regional and district councils it appeared that women were more likely to be selected by the parties for less promising seats, and even by the mid1980s, it was only amongst the then SDP-Liberal Alliance and Independent candidates that women were outperforming men. In 1988 Bochel and Denver argued that this seemed to be occurring for a number of reasons: '...there are not enough women candidates in the first place, and for a variety of reasons, those that are available are not given a high enough proportion of winnable seats by their parties' (Bochel and Denver, 1988). Four years later they suggested that 'This is partly because more women are candidates for the less successful parties, but it is also true that women appear to fight less promising seats than men whatever the party they represent' (Bochel and Denver, 1992). Parties also act as points for negotiation and the structuring of demands, including around women's representation and issues ranging from equal pay to family policy, yet, for most of this period Labour, which would be likely to argue that it is the soundest on women's issues, and which professes an egalitarian philosophy, has had the lowest proportion of women candidates of the major parties. Despite that, Labour's dominant position in Scottish politics for much of the period also meant that a relatively high proportion of its women candidates were elected (although consistently lower than the proportion of male candidates). In contrast, while among Independent candidates, who effectively self-select, men have significantly outnumbered women, nevertheless those women who do stand have generally been more likely to be elected than have men. More recently it is worth noting that Labour has increased the proportion of its candidates who are women, and in the most recent set of elections, in 2012, the party implemented, for the first time, a policy of placing female candidates in half of the vacant seats, with the longer-term aim of achieving equality by 2020 . The Greens, too, have introduced a mechanism designed to help with gender balance, although it has not so far achieved this (Kenny and Mackay, 2012).

\section{FIGURE 3 ABOUT HERE}

\section{The electoral system and the introduction of the Single Transferable Vote}

As noted above, the introduction of STV for council elections followed an agreement between Labour and the Liberal Democrats to form a coalition government in Scotland in 2003, and was a result of the Local Governance (Scotland) Act, passed by the Scottish Parliament in 2004. One of the impacts of STV is that a party is unlikely to be able to win all of the seats in a multi-member ward, and a logical course of action is therefore for it to field only as many candidates as the number of seats it might win. In 2007 and 2012 this appeared to contribute to a significant fall in the total number of candidates, with a decline to just over two thousand six hundred and then to just under two thousand five hundred from nearly four thousand two hundred in 2003.

It is sometimes suggested that proportional electoral systems encourage more women candidates, and result in more women being elected (for example, Norris, 1985; Matland, 2005), since parties 
might see it as appropriate to, for example, put forward one male and one female candidate in a ward, although they may not, of themselves, be necessary or sufficient (Lovenduski, 2005; see also Salmond, 2006). However, in Scotland in 2007 there was a clear decline in the proportion of candidates who were female for each of the major parties, and while this was followed by increases for the Conservatives, Labour and SNP in 2012, the proportion remained significantly lower than before the shift to STV. This might, perhaps, be an unforeseen (and possibly temporary) consequence of the change of electoral system, with women losing out in the scramble for selection. It might reflect, or perhaps have been exacerbated by incumbents being more likely to be selected. It might also be that in the past women may have been willing to be selected for hopeless wards, and that under STV there was perceived to be less need for such sacrificial or 'paper' candidates. One other feature of the use of STV was that the multi-member wards were relatively small (three or four members) and it might be that, as Mackay (2004) suggested in a submission to the Equal Opportunities Committee of the Scottish Parliament, wards with a minimum of five seats would enhance the chances of female candidates being elected, as research in other countries has suggested (see also Salmond, 2006). On the other hand, although analysis of the distribution of first preference votes is perhaps of limited use, where the political parties (in this instance Independent candidates are excluded) had both female and male candidates in the same ward, women received more first preference votes than men in sixty-five instances, while men received more than women in sixty-four cases, suggesting that candidates' gender had little impact on voter preferences.

Following the move to STV, the Liberal Democrats initially had the highest proportion of women candidates of the major parties (31.4\% in 2007, although for the Greens the figure was $39.0 \%$ ) while Labour had the lowest (20.3\%). However, in terms of numbers Labour fielded the most women (106) followed by the Liberal Democrats (104), and the Conservatives and SNP (ninety-six each). The 2012 elections saw a drop in the proportion of women candidates for the Liberal Democrats (to $27.5 \%$ ) and a rise for Labour (to $27.2 \%$ ).

Despite the decline in the proportion of women candidates the proportion of women councillors remained exactly the same in 2007 as in 2003 , at $21.8 \%$, before rising somewhat to $24.3 \%$ in 2012 . This perhaps supports the idea, discussed earlier, that in the past many women had been candidates in unwinnable wards. Indeed, the proportion of women candidates who were elected rose markedly, from $23.0 \%$ in 2003 to $44.9 \%$ in 2007 and $50.8 \%$ in 2012, with the latter figure exceeding that of male candidates for the first time.

\section{Women's representation}

There are a range of explanations that can be put forward for the low levels of representation of women in Scottish local government, as with women's political participation more generally. These would include: the responsibilities of family life and caring, which might deter some women from becoming involved in politics, particularly at the level required as a representative; the impact of processes of selection, with, for example, some selectors perhaps being likely to favour male candidates, despite a lack of evidence that women perform less well than their male counterparts; unwillingness on the part of women to put themselves forward; and the sometimes institutionalised masculinity of political culture. There has been considerable evidence over the years about each of these, and of the ways in which they relate to and interact with each other (for example, Bochel and Bochel, 2000; Childs, 2004; Lovenduski, 2005; Stokes, 2005). Brown et al. (1998) addressed some of these in the Scottish context, including in relation to the Westminster Parliament, drawing on interviews with political activists, and suggested that barriers included the geographic distance and the unsocial hours of Parliament, that the rules and attitudes within parties could impact upon both supply and demand for women candidates, and the political culture more generally. 
While there is relatively little evidence on how effective action on each of these may be, the experience of the Labour Party in relation to selection for the Scottish Parliament, and for Westminster, suggests that positive action, such as women-only short lists, twinning and zipping can be successful, if controversial. However, while Mackay and Kenny have noted (2007: 91), 'Women's representation in the Scottish parliament has had great discursive or symbolic appeal; seen by many as a positive sign that things could change and that the future held the promise of equal political power across the different levels of politics', despite that, there is no evidence of the 'contagion effect' spreading to other levels of electoral representation in Scotland (Kenny and Mackay, 2014), so that progress remains limited in local government in Scotland, where, unlike at Westminster and Holyrood, until Labour's initiative in 2012, none of the major parties had taken any form of positive action to improve women's representation at the local government level.

\section{Women's roles on Scottish councils}

Of course, getting elected is an important achievement, and clearly contributes to the descriptive representation of women. However, the presence of women alone may not be sufficient for substantive representation, and clearly the positions that they attain following election are likely to be important, including through the opportunity to initiate 'critical acts' (Dahlerup, 1988). Some have argued that women may be less likely to be represented in the most important political positions than men precisely because they are more important, as with the desirability hypothesis (Smith, Reingold and Owens, 2009; Engstrom, McDonald and Chou, 1988), or that women will catch up with men in senior positions only after they have been in intermediate positions for some time, as with the lag hypothesis (Lovenduski, 2005), although even when women reach leadership positions there can be concern over the extent of their influence (Baer, 2003; Curtin, 2008). While the bulk of the literature on women councillors has focused on barriers to participation and recruitment, including individual circumstances, structural factors and political culture, there has been much less research on the extent to which women progress to senior positions on councils, although in the 1990s and in 2000 Bochel and Bochel (2004) found that in Scotland women were still less likely than men to have progressed to senior positions in elected local government, a contrast to research in England which suggested that women were proportionately as likely as men to hold senior council positions (Young and Rao, 1993).

Looking across the period considered in this article, in the years following the 1974 reforms relatively few women achieved the most senior posts (such as leader or convenor) in Scotland's regional councils, with the first woman to achieve such a position not doing so until 1987, while two women held such posts between 1991 and 1993. At the district level the proportion of such posts held by women was $6 \%$ in 1978 , rising to $22 \%$ in 1993 . This might, perhaps, fit with the desirability hypothesis, with the regional councils' responsibility for key public services such as education and social care, being seen by some as more important. It might also be the case that active participation in such roles at the district level was seen as, and in reality was, more accessible, as it is geographically closer to employment, families and schools, for women who have other demands on their time. In 2007 however, eight councils (19\%) had women as leaders, slightly higher than the proportions in England and Wales at that time (as another point of comparison, five Scottish councils had female chief executives), and women held $25 \%$ of other senior posts.

Moving the analysis away from council leaders to other significant roles within Scotland's local authorities, Table 4 illustrates that the percentage of committee chairs or cabinet portfolios held by women has continued to lag significantly behind the proportion of councillors who are women. 
When the nature of the subject areas covered by women as committee chair or cabinet portfolio holders is analysed, although, as Table 4 clearly shows, the number of women holding such positions was relatively small, on the regional councils there does appear to have been some clustering around issues such as social work, education, and equal opportunities, which might have traditionally been seen as 'women's' topics. At the district council level, while there was more of a spread, leisure, housing and equal opportunities feature significantly, although there were also significant numbers of women chairing buildings, environmental health, finance and general purposes and policy and resources committees. The latter two committees were generally seen as important and powerful committees, and it appears that, typically, around one-fifth of district councils had such a committee chaired by women over the period from 1977 to 1993.

Table 5 looks at the situation on the unitary councils in 2006 and suggests that relatively little had changed, with women's areas of responsibility including clusters around community and education, social work and housing, and health and social justice, although there were also similar numbers in areas such as development and environment and planning and transport, which would be less likely to be seen as concerned with 'women's issues'.

\section{TABLE 5 ABOUT HERE}

Of course, what these figures do not tell us is whether women councillors had sought to be involved in these areas, in which case they might be perceived as actively seeking to substantively represent women, or whether they were allocated those posts as a result of gender stereotyping. While there is little evidence available on this, Bochel and Bochel found, in two studies (2000 and 2008), that women were generally happy with their positions, and in some cases had actively sought them, although at the same time they did not see this as an attempt to represent women's interests. Similarly, they were more supportive than men in similar positions of descriptive representation around ideas like gender and 'race', and suggested that women politicians often have a different style from men, but they did not necessarily believe that women bring different perspectives or policy priorities (Bochel and Bochel, 2008).

\section{Conclusions}

The period from 1974 to 1999 generally saw a steady, if slow, increase in the levels of women's participation in elected local government in Scotland. However, since then, at least as measured by the proportion of candidates and councillors who are women, there is no evidence of further change, with Labour being the only one of the four main parties to have increased the proportion of women among its candidates. Having looked at the position in the country's four main cities earlier in this article, Table 6 returns to them and compares the situation in 1972 and 2012 to show clearly the extent of change; and, as the article illustrates, this pattern has been largely repeated in councils across Scotland.

\section{TABLE 6 ABOUT HERE}


Nevertheless, after more than three decades, and following significant structural and political change, the levels of women's representation in Scottish local government remain low. Indeed, women candidates continue to be less likely to be elected than their male counterparts, although these consistently lower levels of rates of election of women candidates appear to have nothing to do with their merits as candidates, and a great deal to do with the seats that they are selected to fight.

The same arguments can also be applied to the position within councils, where the proportion of senior posts held by women continues to be lower than the proportion of councillors who are women. It may be that this is, at least in part, in line with the lag hypothesis, and that the imbalance may reduce over time. However, this is far from certain.

The shortcomings of the situation within local government are made more apparent by the higher levels of representation now present in the Scottish Parliament, which since 1997 has itself had responsibility for the country's system of local government (and which in 2015 had a woman as First Minister with four of the other nine Scottish Cabinet posts also being held by women), and they continue despite post-devolution changes such as the introduction of the single transferable vote electoral system and salaries for councillors. It may therefore be that in order to deliver higher numbers of women councillors in Scotland, and to increase the levels of women's representation in more senior roles in councils, strong action by either or both of the Scottish government or the political parties will be necessary (see also Mackay and Kenny, 2007 and 2012). Despite the progress made between 1974 and 1999, the period since then has demonstrated that there is no inevitability about further improvements in women's representation at council level. However, if some or all of the arguments referred to at the start of this article are accepted, so that legitimacy, justice, democracy and participation, and policy making can be improved through the greater descriptive and substantive representation of women, then clearly local government and the political parties in Scotland are missing an opportunity to enhance these things.

\section{Acknowledgement}

We are grateful to two anonymous reviewers for their comments on this article.

\section{References}

Baer, D. (2003). Women, women's organisations and political parties. In S. Carroll (ed.) Women and American Politics: New Questions, New Direction. Oxford: Oxford University Press. Bochel, C. and A. Evans (2007). Inclusive policy making. In H. Bochel and S. Duncan (eds), Making Policy in Theory and Practice, 105-23. Bristol: Policy Press.

Bochel, C. and H. Bochel (2000). The Careers of Councillors. Aldershot: Ashgate Bochel, C. and H. Bochel (2004). Modernisation or backward step? Women councillors and new decision-making structures in local government. Local Government Studies, vol. 30, 36-50. Bochel, C. and H. Bochel (2008). Women 'leaders' in local government in the UK. Parliamentary Affairs, vol. 61, 426-41.

Bochel, H. and A. Defty (2012). A more representative chamber: representation and the House of Lords. Journal of Legislative Studies, vol. 18, 82-97.

Bochel, J. and D. Denver (1974). The Scottish Local Government Elections 1974. Edinburgh: Scottish Academic Press. 
Bochel, J. and D. Denver (1977). The Scottish District Elections 1977. Dundee: Election Studies. Bochel, J. and D. Denver (1988). Scottish District Elections 1988. Dundee: Election Studies. Bochel, J. and D. Denver (1992). Scottish District Elections 1992. Dundee: Election Studies. Breitenbach, E., A. Brown and F. Myers (1998). Understanding Women in Scotland. Feminist review, no. 58, 44-65.

Breitenbach, E. (2005). Gender Equality Policies in Scotland Since Devolution. Scottish Affairs, no. 56, 10-21.

Brown, A. (1999). Taking their place in the new house: women and the Scottish Parliament. Scottish Affairs, vol. 28, 44-50.

Brown, A. (2000). Designing the New Scottish Parliament. Parliamentary Affairs, vol. 55, 542-56. Brown, A., T. Donaghy, F. Mackay and E. Meehan (2002). Women and constitutional change in Scotland and Northern Ireland. Parliamentary Affairs, vol. 55, 71-84.

Brown, A., McCrone, D. and Paterson, L. (1998). Politics and Society in Scotland. Basingstoke: Macmillan.

Cairney, P. and N. McGarvey (2013). Scottish Politics. Basingstoke: Palgrave Macmillan.

Celis, K. and S. Childs (2008). Introduction: The Descriptive and Substantive Representation of Women: New Directions. Parliamentary Affairs, vol. 61, 419-25.

Childs, S. (2004). New Labour's Women MPs: Women Representing Women. London: Routledge.

Curtin, J. (2008). Women, political leadership and substantive representation: the case of New

Zealand. Parliamentary Affairs, vol. 61, 490-504.

Dahlerup, D. (1988). From a small to a large minority: women in Scandinavian politics. Scandinavian Political Studies, vol. 11, 275-98.

Denver, D. and H. Bochel (2007). A Quiet Revolution: STV and the Scottish Council Elections of 2007. Scottish Affairs, no. 61, 1-17.

Denver, D., J. Mitchell, C. Pattie and H. Bochel (2000). Scotland Decides: The Devolution Issue and the Scottish Referendum. London: Frank Cass.

Electoral Commission (2004). Gender and Political Participation. London: Electoral Commission. Engstrom, R., M. McDonald and B. Chou (1988). The desirability hypothesis and the election of women to city councils: a research note. State and Local Government Review, vol. 20, 38-40. Gould, R. (2007). Independent review of the Scottish Parliamentary and local government elections 3 May 2007. Edinburgh: Electoral Commission.

Hansard Society (2011). Audit of Political Engagement: The 2011 Report. London: Hansard Society. Hansard Society (2014). Audit of Political Engagement 11: The 2014 Report. London: Hansard Society.

Hassan, G. (ed) (2009). The Modern SNP: From Protest to Power. Edinburgh: Edinburgh University Press.

Kenny, M. and F. Mackay (2011). In the balance: women and the 2011 Scottish Parliament elections. Scottish Affairs, vol. 76, 74-86.

Kenny, M. and F. Mackay (2012). Less male, pale and stale: women and the 2012 Scottish local elections. Scottish Affairs, vol. 80, 20-32.

Kenny, M. and F. Mackay (2014). When is contagion not very contagious? Dynamics of women's political representation in Scotland. Parliamentary Affairs, vol. 67, 866-886.

Levy, C. (1992). A Woman's Place? The Future Scottish Parliament. In L. Paterson and D. McCrone (eds) The Scottish Government Yearbook 1992, 59-73. Edinburgh: Unit for the Study of Government in Scotland.

Lovenduski, J. (2005) Feminizing Politics. Cambridge: Polity.

Mclver, D. (ed) (1996). The Liberal Democrats. Hemel Hemstead: Prentice Hall/Harvester Wheatsheaf.

Mackay, F. (2004). The gender impact of Scottish local government reform, submission to the Equal Opportunities Committee of the Scottish Parliament.

Mackay, F. and M. Kenny (2007). Women's representation in the 2007 Scottish Parliament: temporary setback or return to the norm. Scottish Affairs, vol. 60, 80-93. 
Matland, R. (2005). Enhancing women's political participation: legislative recruitment and electoral systems. In A. Karam (ed) Women in Parliament: Beyond numbers. 93-138. Stockholm: International Institute for Democracy and Electoral Assistance.

Mitchell, J. (2000). New Parliament, New Politics in Scotland. Parliamentary Affairs, vol. 55, 605-21. Norris, P. (1985). Women's Legislative Participation in Western Europe. West European Politics, vol. 8, 90-101.

Parry, G., G. Moyser and N. Day (1992). Political Participation and Democracy in Britain. Cambridge: Cambridge University Press.

Pattie, C., P. Seyd and P. Whiteley (2004). Citizens and Politics: Democracy and Participation in Twenty-First Century Britain. Cambridge: Cambridge University Press.

Phillips, A. (2005). The Politics of Presence. Oxford: Clarendon Press.

Russell, M., F. Mackay and L. McAllister (2002). Women's representation in the Scottish Parliament and the National Assembly for Wales: party dynamics for achieving critical mass. Journal of Legislative Studies, vol. 8, 49-76.

Salmond, R. (2006). Proportional Representation and Female Parliamentarians. Legislative Studies Quarterly, vol. 31, 175-204.

Schwindt-Bayer, L. and W. Mishler (2005). An integrated model of women's representation. Journal of Politics, vol. 67, 407-28.

Smith, A., B. Reingold and M. Owens (2009). Women and politics in cities: determinants of the descriptive representation of women in city halls and councils, paper presented to the annual meetings of the American Political Science Association, 3-6 September, Toronto.

Stokes, W. (2005). Women in Contemporary Politics. Cambridge: Polity.

Young, K. and N. Rao (1993). Coming to Terms with Change? The Local Government Councillor in 1993. York: Joseph Rowntree Foundation/LGC Communications.

Wheatley, Lord (Chairman) (1969). Royal Commission on Local Government in Scotland: Report. Edinburgh: HMSO.

Wilson, D. and C. Game (2011). Local Government in the United Kingdom. Basingstoke: Palgrave Macmillan.

Woman's Claim of Right Group (1991). A Woman's Claim of Right in Scotland. Edinburgh: Polygon. 
Table 1 Percentage share of the vote in general elections in Scotland, 1974-2010

\begin{tabular}{lccccccccccc} 
& 1970 & $1974 F e b$ & $19740 c t$ & 1979 & 1983 & 1987 & 1992 & 1997 & 2001 & 2005 & 2010 \\
\hline Con & 38 & 33 & 25 & 31 & 28 & 24 & 26 & 18 & 16 & 16 & 17 \\
Lab & 45 & 37 & 36 & 42 & 35 & 42 & 39 & 42 & 44 & 40 & 42 \\
Lib/LD & 6 & 8 & 8 & 9 & 25 & 19 & 13 & 15 & 16 & 23 & 19 \\
SNP & 11 & 22 & 30 & 17 & 12 & 14 & 22 & 17 & 20 & 18 & 20
\end{tabular}


Table 2 Percentage of seats won in general elections in Scotland, 1974-2010

\begin{tabular}{lccccccccccc} 
& 1970 & $1974 F e b$ & $19740 c t$ & 1979 & 1983 & 1987 & 1992 & 1997 & 2001 & 2005 & 2010 \\
\hline Con & 32 & 30 & 23 & 31 & 29 & 14 & 15 & 0 & 1 & 2 & 2 \\
Lab & 62 & 56 & 58 & 62 & 57 & 69 & 68 & 78 & 78 & 69 & 69 \\
Lib/LD & 4 & 4 & 4 & 4 & 11 & 13 & 13 & 14 & 14 & 19 & 19 \\
SNP & 1 & 10 & 15 & 3 & 3 & 4 & 4 & 8 & 7 & 10 & 10
\end{tabular}


Figure 1 Percentage of women candidates by party, 1974-2012

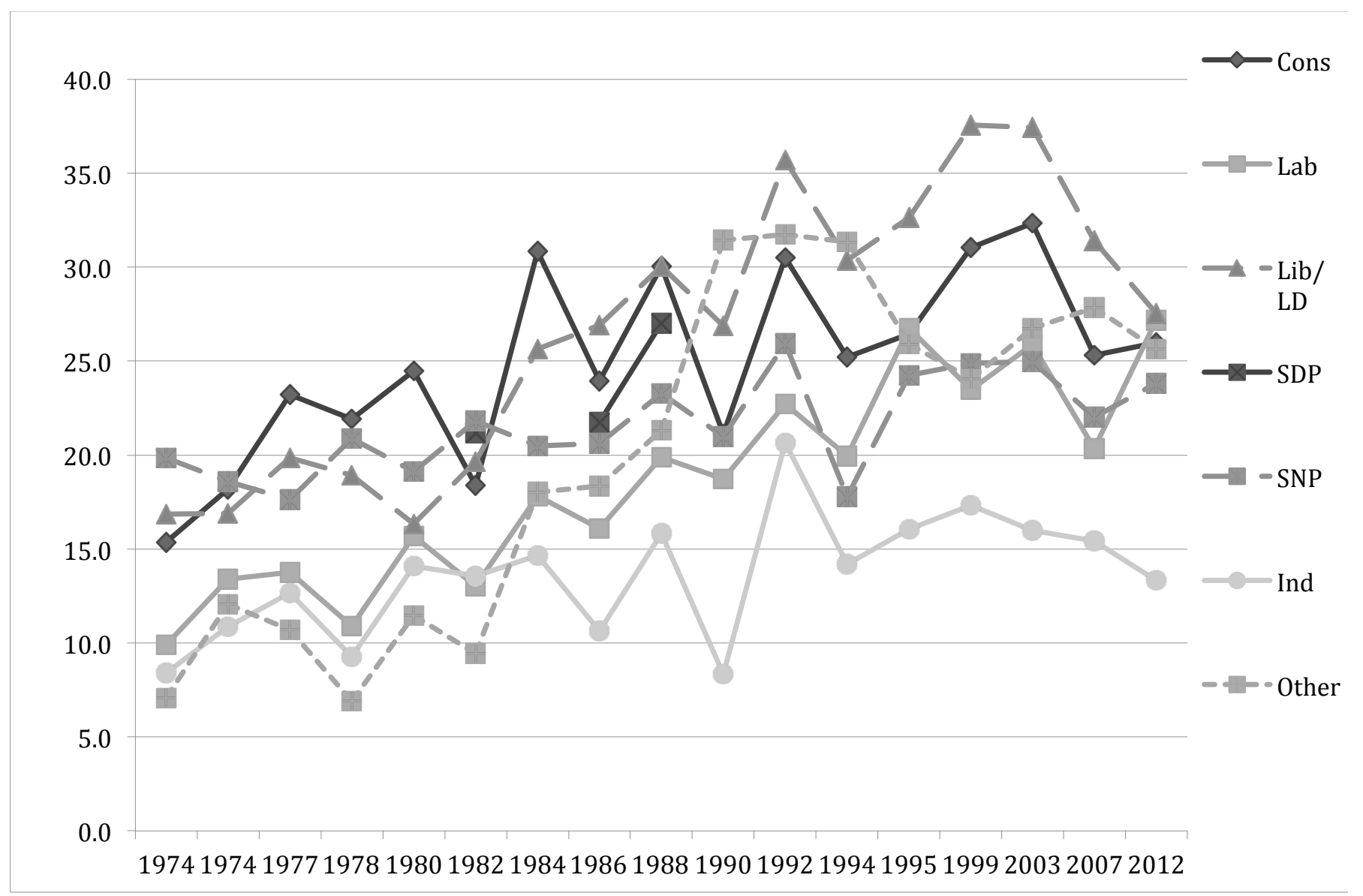


Table 3 Percentage of councillors who are women, 1974-2012

\begin{tabular}{|c|c|c|c|c|c|c|c|c|c|c|c|c|c|c|c|c|c|}
\hline & 1974 & 1974 & 1977 & 1978 & 1980 & 1982 & 1984 & 1986 & 1988 & 1990 & 1992 & 1994 & 1995 & 1999 & 2003 & 2007 & 2012 \\
\hline Tier & Reg & Dist & Dist & Reg & Dist & Reg & Dist & Reg & Dist & Reg & Dist & Reg & & & & & \\
\hline & 10.3 & 12.2 & 14.1 & 12.2 & 14.5 & 12.7 & 17.1 & 15.1 & 19.7 & 16.2 & 21.5 & 17.4 & 23.0 & 24.5 & 23.3 & 21.8 & 24.3 \\
\hline
\end{tabular}

*From 1974 to 1994 elections were held for the two tier system of local government (with elections to both held simultaneously in May 1974); since 1995 they have been for the unitary system. 
Figure 2 Percentage of female and male candidates elected, 1974-2012




Figure 3 Percentage of women candidates elected by party, 1974-2012




Table 4 Committee chairs/cabinet portfolios in Scottish councils, 1977-2007

\begin{tabular}{lcccc} 
& $\begin{array}{c}\text { No. of chairs } \\
\text { No. of chairs held } \\
\text { by women }\end{array}$ & $\begin{array}{c}\text { \% of chairs held } \\
\text { by women }\end{array}$ & $\begin{array}{c}\text { \% of councillors } \\
\text { who were women }\end{array}$ \\
\hline Regional councils & 89 & 3 & 3 & 10 \\
1977 & 93 & 9 & 10 & 17 \\
1985 & 104 & 18 & 17 & 21 \\
1993 & & & & 13 \\
District councils & 329 & 36 & 11 & 17 \\
1977 & 348 & 46 & 13 & 22 \\
1985 & 365 & 61 & 17 & 22 \\
1993 & & & &
\end{tabular}


Table 5 Female cabinet post/committee chairs in Scottish councils, 2006

Community/Education/Children

Health/Social Justice

Policy and Strategy

3

Appointments

1

Infrastructure/Corporate/Finance 3

Social Work/Housing 5

Planning and transport 4

Development/Environment 4

Culture/Leisure $\quad 1$

Commercial 1

Standards/Scrutiny 4 
Table 6 Percentage of women candidates and councillors in Scotland's four main cities, 1972 and 2012

1972

Candidates Councillors

Aberdeen

Dundee

Edinburgh

Glasgow
9

8

12

16
0

0

9

16
2012

Candidates Councillors

$26 \quad 28$

$19 \quad 21$

$24 \quad 26$

$23 \quad 30$ 